\title{
Pulmonary Arterial Hypertension Indicator
}

National Cancer Institute

\section{Source}

National Cancer Institute. Pulmonary Arterial Hypertension Indicator. NCI Thesaurus.

Code C135379.

An indication as to whether there is hypertension in the pulmonary artery. 